\title{
MOTOR SKILLS: MOTOR FITNESS STRUCTURE OF 9-YEAR-OLD BOYS
}

\author{
Dmytro Petrov ${ }^{\mathrm{ABCD}}$, Oleg Khudoliii ${ }^{1 \mathrm{ABCD}}$, Mirosława Cieślicka ${ }^{2 \mathrm{ABCD}}$
}

\author{
${ }^{1}$ H. S. Skovoroda Kharkiv National Pedagogical University
}

${ }^{2}$ Collegium Medicum: Bydgoszcz, Kujawsko Pomorskie

Authors' Contribution: A - Study design; B - Data collection; C - Statistical analysis; D - Manuscript Preparation; E - Funds Collection

DOI: $10.17309 / \mathrm{jltm} .2020 .2 .02$

\begin{abstract}
The purpose of the study was to determine the place of motor skills in the motor fitness structure of 9-year-old boys. Materials and methods. The study participants were 489 -year-old boys. The children and their parents were informed about all the features of the study and gave their consent to participate in the experiment. The study used the following research methods: analysis of scientific and methodological literature, pedagogical observations, testing of motor fitness, probabilistic approach to assessing the learning process, methods of mathematical statistics. In the experiment, the study controlled the level of proficiency in the following exercises: "Rope climbing in two steps", "Rope climbing in three steps", "One leg swing upward circle".

Results. The level of fitness of the 9-year-old boys is homogeneous by the development of "agility", "movement coordination", "speed strength", and "endurance"; inhomogeneous - by the development of flexibility, arm strength, vestibular stability, and the level of proficiency in rope climbing.

The most informative indicators that determine the level of 9-year-old boys' motor fitness are: No. 12 "Rope climbing in two steps, level of proficiency" ( $r=0.960)$; No. 13 "Rope climbing in three steps, level of proficiency" $(r=0.960)$; No. 14 "One leg swing upward circle, level of proficiency" ( $r=0.875)$; No. 10 "Maintenance of stable posture - standing on one leg with closed eyes, $s$ " ( $r=0.683)$.

Conclusions. Based on factor analysis, it was found that the level of proficiency in the exercises determines the variation of testing results by $24.287 \%$, and the development of motor skills is a priority in the educational process at primary school.

The level of proficiency in rope climbing shows that the exercises are difficult for 9-year-old boys to perform. Based on the data analysis, it can be argued that the comprehensive development of motor abilities ensures the formation of motor skills, and the improvement of the level of development of 9-year-old boys' arm flexors will positively influence the educational process effectiveness.

Keywords: 9-year-old boys, motor skills, motor abilities, factor analysis.
\end{abstract}

\section{Introduction}

In research papers, motor activity is viewed as a necessary condition for developing cognitive functions and improving health-related quality of life (Evaristo, Moreira, Lopes, Abreu, Agostinis-Sobrinho, Oliveira-Santos, Póvoas, Oliveira, Santos, \& Mota, 2018; Hsieh, Fung, Tsai, Chang, Huang, \& Hung, 2018; Kaiser-Jovy, Scheu, \& Greier, 2017). The importance of increasing primary schoolchildren's motor activity is pointed out by Krivolapchuk and Chernova (2019), Krivolapchuk, Chernova, \& Gerasimova(2020), Krivolapchuk, Gerasimova, Myshiakov, \& Chicherin (2020).

(c) Petrov, D., Khudolii, O., Cieślicka, M., 2020.
A physical education class at school is the main form of motor activity, which ensures the development of motor skills and motor abilities (Bădicu, 2018; Hiley, Schmid, \& Yeadon, 2019; Peng, Li, \& Zhu, 2018), as well as the development of cognitive function during physical education (SánchezLópez, Cavero-Redondo, Âlvarez-Bueno, Ruiz-Hermosa, Pozuelo-Carrascosa, Díez-Fernández, Gutierrez-Díaz del Campo, Pardo-Guijarro, \& Martínez-Vizcaíno, 2019; Moradi, Damirchi, Narimani, Esmaeilzadeh, Dziembowska, Azevedo, \& Do Prado, 2019).

It was found that the effectiveness of motor skills development depends on consistent solving of learning tasks and rational application of methods aimed at developing motor abilities and mastering motor tasks (Khudolii, 2019; Ivashchenko, 2020; Khudolii, Iermakov, \& Bartik, 2020). 
However, further research is needed to determine the leading role of motor skills development in the primary school educational environment.

The purpose of the study was to determine the place of motor skills in the motor fitness structure of 9-year-old boys.

\section{Materials and Methods}

\section{Study Participants}

The study participants were 489 -year-old boys. The children and their parents were informed about all the features of the study and gave their consent to participate in the experiment.

\section{Organization of the Study}

The study used the following research methods: analysis of scientific and methodological literature, pedagogical observations, testing of motor fitness, probabilistic approach to assessing the learning process, methods of mathematical statistics.

The study recorded the indicators of height $(\mathrm{cm})$, body weight (kg), and the results in tests No. 3 "Standing long jump (cm)", No. 4 "Middle- and long-distance running. $300 \mathrm{~m}$ running (s)", No. 5 "30 m sprint running from a standing start (s)", No. 6 "Seated forward bend (cm)", No. 7 "Mixed hang rope pull-ups (times)", No. 8 "Shuttle run $4 \times 9$ m (s)", No. 9 "Combined movements of arms, torso and legs (points)", No. 10 "Maintenance of stable posture - standing on one leg with closed eyes (s)", No. 11 "Walking along straight line after 5 rotations (deviations in $\mathrm{cm}$ )".

The study recorded the primary schoolchildren's level of proficiency in gymnastic exercises. The coefficient was determined by the formula: $\mathrm{p}=(\mathrm{m} / \mathrm{n}) \times 100$, where $\mathrm{p}$ is the level of proficiency, $m$ is the number of successfully performed exercises, $\mathrm{n}$ is the total number of attempts to perform the exercise. In the experiment, the study controlled the level of proficiency in the following exercises: "Rope climbing in two steps", "Rope climbing in three steps", "One leg swing upward circle".

\section{Statistical Analysis}

The study materials were processed using the IBM SPSS 20 statistical analysis software. Factor analysis was performed. In the factor analysis, the study used the model of principal components with the rotation method: Varimax with Kaiser Normalization.

The study protocol was approved by the Ethical Committee of the University. In addition, the children and their parents or legal guardians were fully informed about all the features of the study, and a signed informed-consent document was obtained from all the parents.

\section{Results}

Table 1 shows the results of testing the 9-year-old boys' motor fitness.

The analysis of the coefficients of variation of testing results showed that the 9-year-old boys' fitness is homogeneous
Table 1. The results of testing the 9-year-old boys' motor fitness $(n=48)$

\begin{tabular}{|c|c|c|c|c|}
\hline No. & Indicator & $\mathbf{X}$ & $\mathbf{s}$ & V \\
\hline$\overline{1}$ & Height, $\mathrm{cm}$ & 135.88 & 5.43 & 4 \\
\hline 2 & Body weight, kg & 32.77 & 5.48 & 16.72 \\
\hline 3 & Standing long jump, cm & 135.42 & 10.21 & 7.54 \\
\hline 4 & $300 \mathrm{~m}$ running, $\mathrm{s}$ & 100.63 & 17.32 & 17.21 \\
\hline 5 & $\begin{array}{l}30 \mathrm{~m} \text { running from a standing start, } \\
\mathrm{s}\end{array}$ & 6.35 & .44 & 6.93 \\
\hline 6 & Seated forward bend, $\mathrm{cm}$ & 4.56 & 3.18 & 69.74 \\
\hline 7 & Mixed hang rope pull-ups, times & 4.79 & 1.91 & 39.87 \\
\hline 8 & Shuttle run $4 \times 9 \mathrm{~m}, \mathrm{~s}$ & 12.24 & .67 & 5.47 \\
\hline 9 & $\begin{array}{l}\text { Combined movements of arms, } \\
\text { torso and legs, points }\end{array}$ & 8.28 & .90 & 10.87 \\
\hline 10 & $\begin{array}{l}\text { Maintenance of stable posture - } \\
\text { standing on one leg with closed } \\
\text { eyes, s }\end{array}$ & 20.83 & 11.11 & 53.34 \\
\hline 11 & $\begin{array}{l}\text { Walking along straight line after } 5 \\
\text { rotations, deviations in } \mathrm{cm}\end{array}$ & 81.56 & 66.06 & 81 \\
\hline 12 & $\begin{array}{l}\text { Rope climbing in two steps, level of } \\
\text { proficiency }\end{array}$ & 32.29 & 16.40 & 50.79 \\
\hline 13 & $\begin{array}{l}\text { Rope climbing in three steps, level of } \\
\text { proficiency }\end{array}$ & 32.29 & 16.40 & 50.79 \\
\hline 14 & $\begin{array}{l}\text { One leg swing upward circle, level of } \\
\text { proficiency }\end{array}$ & 53.75 & 17.09 & 31.8 \\
\hline
\end{tabular}

by the following tests: No. 1 "Height, cm" (4\%); No. 8 "Shuttle run $4 \times 9 \mathrm{~m}, \mathrm{~s}$ " (5.47\%); No. 5 " $30 \mathrm{~m}$ running from a standing start, s" (6.93\%); No. 3 "Standing long jump, cm" (7.54\%); No. 9 "Combined movements of arms, torso and legs, points" (10.87\%); No. 2 "Body weight, kg" (16.72\%); No. 4 "300 m running, s" (17.21\%); No. 14 "One leg swing upward circle, level of proficiency" (31.8\%).

The level of the boys' fitness is inhomogeneous by the results of tests: No. 6 "Seated forward bend, cm" (69.74); No. 10 "Maintenance of stable posture - standing on one leg with closed eyes, s" (53.34\%); No. 7 "Mixed hang rope pull-ups, times" (39.87\%); No. 11 "Walking along straight line after 5 rotations, deviations in cm" (81\%); No. 12 "Rope climbing in two steps, level of proficiency"; No. 13 "Rope climbing in three steps, level of proficiency" (50.79\%).

The coefficient of variation in terms of the level of proficiency in the exercises "Rope climbing in two steps, level of proficiency" and "Rope climbing in three steps, level of proficiency" shows that the exercises are difficult to perform.

Thus, the level of fitness of the 9-year-old boys is homogeneous by the development of "agility", "movement coordination", "speed strength", and "endurance"; inhomogeneous by the development of flexibility, arm strength, vestibular stability, and the level of proficiency in rope climbing.

Table 2 shows the results of factor analysis. The analysis identified four factors that explain $66.348 \%$ of the variation of results.

The first factor has a weight of $24.287 \%$. With the factor, the greatest correlation is in the level of proficiency in exercises: No. 12 "Rope climbing in two steps, level of proficiency" $(r=0.969)$; No. 13 "Rope climbing in three steps, level of proficiency" $(r=0.969)$; No.14 "One leg swing upward circle, level of proficiency" ( $r=0.933)$; No. 7 "Mixed hang rope 
Table 2. The results of factor analysis. Boys aged $9(n=48)$

\begin{tabular}{|c|c|c|c|c|c|c|}
\hline \multirow{2}{*}{ No } & \multirow{2}{*}{ Indicator } & \multicolumn{4}{|c|}{ Component } & \multirow{2}{*}{$\mathbf{h}^{2}$} \\
\hline & & 1 & 2 & 3 & 4 & \\
\hline 1 & Height, cm & & 0.641 & & & 0.471 \\
\hline 2 & Body weight, kg & & 0.815 & & & 0.672 \\
\hline 3 & Standing long jump, $\mathrm{cm}$ & & -0.605 & & 0.400 & 0.541 \\
\hline 4 & $300 \mathrm{~m}$ running, s & & 0.631 & 0.317 & 0.361 & 0.664 \\
\hline 5 & $30 \mathrm{~m}$ running from a standing start, $\mathrm{s}$ & & 0.594 & & & 0.436 \\
\hline 6 & Seated forward bend, $\mathrm{cm}$ & & & & 0.632 & 0.453 \\
\hline 7 & Mixed hang rope pull-ups, times & 0.716 & -0.309 & & & 0.612 \\
\hline 8 & Shuttle run $4 \times 9 \mathrm{~m}, \mathrm{~s}$ & & & -0.474 & -0.607 & 0.665 \\
\hline 9 & Combined movements of arms, torso and legs, points & & -0.319 & 0.631 & 0.344 & 0.631 \\
\hline 10 & Maintenance of stable posture - standing on one leg with closed eyes, s & & & 0.695 & -0.398 & 0.683 \\
\hline 11 & Walking along straight line after 5 rotations, deviations in $\mathrm{cm}$ & & & -0.626 & 0.460 & 0.667 \\
\hline 12 & Rope climbing in two steps, level of proficiency & 0.969 & & & & 0.960 \\
\hline 13 & Rope climbing in three steps, level of proficiency & 0.969 & & & & 0.960 \\
\hline \multirow[t]{2}{*}{14} & One leg swing upward circle, level of proficiency & 0.933 & & & & 0.875 \\
\hline & $\%$ & 24.287 & 18.219 & 12.269 & 11.572 & 66.348 \\
\hline
\end{tabular}

pull-ups, times" ( $r=0.716)$. The factor is called the level of proficiency in gymnastic exercises.

The second factor has a weight of $18.219 \%$. With the factor, the greatest correlation is in: No. 1 "Height, cm" $(r=0.641)$; No. 2 "Body weight, kg" $(r=0.815)$; No. 3 "Standing long jump, cm" ( $r=-0.605)$; No. 4 "300 m running, s" $(r=0.631)$. The factor is called physical development.

The third factor has a weight of $12.269 \%$. With the factor, the greatest correlation is in: No. 9 "Combined movements of arms, torso and legs, points" ( $r=0.631)$; No. 10 "Maintenance of stable posture - standing on one leg with closed eyes, $s$ " $(r=0.695)$; No. 11 "Walking along straight line after 5 rotations, deviations in $\mathrm{cm}$ " $(r=-0.626)$. The factor is called movement coordination and vestibular stability.

The fourth factor has a weight of $11.572 \%$. With the factor, the greatest correlation is in: No. 6 "Seated forward bend, $\mathrm{cm}$ " ( $r=0.632)$; No. 8 "Shuttle run $4 \times 9 \mathrm{~m}, \mathrm{~s}$ " $(r=-0.607)$. The factor is called general movement coordination.

The analysis of similarities made it possible to identify the most informative indicators that determine the level of motor fitness of the 9-year-old boys:

- No. 12 "Rope climbing in two steps, level of proficiency" $(r=0.960)$;

- No. 13 "Rope climbing in three steps, level of proficiency" $(r=0.960)$;

- No. 14 "One leg swing upward circle, level of proficiency" $(r=0.875)$;

- No. 10 "Maintenance of stable posture - standing on one leg with closed eyes, $s$ " $(r=0.683)$.

The graphic representation of a two-factor model of testing results shows that the analysis identifies two sets of data with high correlation coefficients. The first set includes tests No. 12, 13, 14, and 7, which characterize the level of proficiency in gymnastic exercises and relative arm strength; the second - tests No. 2, 1, 4, 5, and 3, which characterize physical development and the level of development of speed strength, agility, and endurance (see Fig. 1).

Thus, the 9-year-old boys' motor fitness is determined, on the one hand, by the level of development of arm strength and the level of proficiency in gymnastic exercises; on the

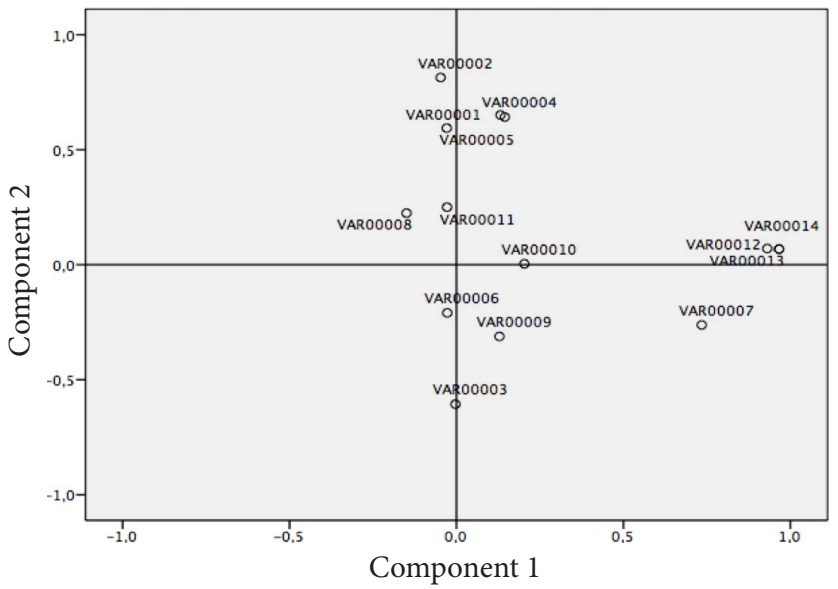

Fig. 1. The graphic representation of a two-factor model of testing results: 1 - height $(\mathrm{cm}), 2$ - body weight $(\mathrm{kg}), 3$ - "Standing long jump $(\mathrm{cm})$ ", 4 - "Middle- and long-distance running. $300 \mathrm{~m}$ running (s)", 5 - "30 m sprint running from a standing start (s)", 6 - "Seated forward bend (cm)", 7 - "Mixed hang rope pull-ups (times)", 8 - "Shuttle run $4 \times 9$ m (s)", 9 - "Combined movements

of arms, torso and legs (points)", 10 - "Maintenance of stable posture - standing on one leg with closed eyes (s)", 11 - "Walking along straight line after 5 rotations (deviations in $\mathrm{cm}$ )", 12 - "Rope climbing in two steps, level of proficiency", 13 - "Rope climbing in three steps, level of proficiency", 14 - "One leg swing upward circle, level of proficiency".

other hand, by physical development and the level of development of speed strength, agility, and endurance.

\section{Discussion}

The paper assumed that motor skills occupy a leading place in the structure of motor fitness of 9-year-old boys. So, the level of proficiency in exercises determines the variation of testing results by $24.287 \%$. Thus, the study's findings make it possible to accept the research hypothesis on the leading role of motor skills development in physical education classes at primary school. 
The analysis of the coefficients of variation points to heterochrony in the development of the 9-year-old boys' motor abilities. The level of proficiency in rope climbing indicates that the exercises are difficult for 9-year-old boys to perform. Based on the data analysis, it can be argued that the comprehensive development of motor abilities ensures the formation of motor skills, and the improvement of the level of development of 9-year-old boys' arm flexors will positively influence the educational process effectiveness.

The obtained results supplement the data on the relationship between the level of proficiency in gymnastic exercises and the level of development of strength and movement coordination (Ivashchenko, Berezhna, \& Cieślicka, 2020; Ivashchenko, \& Sirichenko, 2020). As with 7-year-old boys, there is considerable variation in the results of test No. 7 "Mixed hang rope pull-ups, times" (Ivashchenko, Berezhna, \& Cieślicka, 2020).

The results of factor analysis confirm the integrity of the process of motor skills formation and motor abilities development in children (Khudolii, Ivashchenko, \& Chernenko, 2015; Ivashchenko, Iermakov, Khudolii, Cretu, \& Potop, 2017).

The results of the study highlight the need to develop a teaching technique, which would include the development of motor abilities and series of learning tasks (Ivashchenko, Khudolii, Iermakov, Chernenko, \& Holovko, 2015), organization of a series of classes (Hellin, Garcia-Jimenez, \& Garcia-Pellicer, 2019a; Hellin, Garcia-Jimenez, \& Garcia-Pellicer, 2019b; Groffik, Mitáš, Jakubec, Svozil, \& Frömel, 2020), and exercise modes (Ivashchenko, \& Cieślicka, 2017; Cieślicka, \& Ivashchenko, 2017; Marchenko, \& Kovalenko, 2020).

Thus, the 9-year-old boys' motor fitness is determined, on the one hand, by the level of development of arm strength and the level of proficiency in gymnastic exercises; on the other hand, by physical development and the level of development of speed strength, agility, and endurance.

\section{Conclusions}

Based on factor analysis, it was found that the level of proficiency in the exercises determines the variation of testing results by $24.287 \%$, and the development of motor skills is a priority in the educational process at primary school.

The level of proficiency in rope climbing shows that the exercises are difficult for 9-year-old boys to perform. Based on the data analysis, it can be argued that the comprehensive development of motor abilities ensures the formation of motor skills, and the improvement of the level of development of 9-year-old boys' arm flexors will positively influence the educational process effectiveness.

\section{Acknowledgement}

The study was carried out in accordance with the plan of research work of the Department of Theory and Methodology of Physical Education of H. S. Skovoroda Kharkiv National Pedagogical University.

\section{Conflict of Interests}

The authors declare no conflicts of interest.

\section{References}

Evaristo, O. S., Moreira, C., Lopes, L., Abreu, S., AgostinisSobrinho, C., Oliveira-Santos, J., Póvoas, S., Oliveira, A., Santos, R., \& Mota, J. (2018). Associations between physical fitness and adherence to the Mediterranean diet with health-related quality of life in adolescents: Results from the LabMed Physical Activity Study. European Journal of Public Health, 28(4), 631-635. Scopus. https://doi.org/10.1093/eurpub/cky043

Hsieh, S.-S., Fung, D., Tsai, H., Chang, Y.-K., Huang, C.-J., \& Hung, T.-M. (2018). Differences in working memory as a function of physical activity in children. Neuropsychology, 32(7), 797-808. Scopus. https://doi.org/10.1037/neu0000473

Kaiser-Jovy, S., Scheu, A., \& Greier, K. (2017). Media use, sports activities, and motor fitness in childhood and adolescence. Wiener Klinische Wochenschrift, 129(13-14), 464-471. Scopus. https://doi.org/10.1007/s00508-017-1216-9

Krivolapchuk, I. A., \& Chernova, M. B. (2019). Peculiarities of the Factorial Structure of the Functional State in Children Aged 9-10 Years. Human Physiology, 45(1), 30-39. Scopus. https://doi.org/10.1134/S0362119718050067

Krivolapchuk, I. A., Chernova, M. B., \& Gerasimova, A. A. (2020). Effect of regular physical activity of various intensity on the functional status of 5-6 and 6-7-year-old children. Human Sport Medicine, 20(2), 71-79. Scopus. https://doi.org/10.14529/HSM200209

Krivolapchuk, I. A., Gerasimova, A. A., Myshiakov, V. V., \& Chicherin, V. P. (2020). The effect of anaerobic glycolytic performance on the functional status and cognitive efficiency in primary schoolchildren. Human Sport Medicine, 19(2), 29-36. Scopus. https://doi.org/10.14529/HSM19S204

Moradi, A., Damirchi, E. S., Narimani, M., Esmaeilzadeh, S., Dziembowska, I., Azevedo, L. B., \& Do Prado, W. L. (2019). Association between physical and motor fitness with cognition in children. Medicina (Lithuania), 55(1) Scopus. https://doi.org/10.3390/medicina55010007

Sánchez-López, M., Cavero-Redondo, I., Álvarez-Bueno, C., Ruiz-Hermosa, A., Pozuelo-Carrascosa, D. P., DíezFernández, A., Gutierrez-Díaz del Campo, D., PardoGuijarro, M. J., \& Martínez-Vizcaíno, V. (2019). Impact of a multicomponent physical activity intervention on cognitive performance: The MOVI-KIDS study. Scandinavian Journal of Medicine and Science in Sports, 29(5), 766-775. Scopus. https://doi.org/10.1111/sms.13383

Bădicu, G. (2018). Teaching Methods Used in Primary Education for Making Physical Education Class More Effective. Teoriâ ta Metodika Fizičnogo Vihovannâ, 18(2), 86-92. https://doi.org/10.17309/tmfv.2018.2.05

Bores-García, D., Hortigüela-Alcalá, D., Fernandez-Rio, F. J., González-Calvo, G., \& Barba-Martín, R. (2020). Research on Cooperative Learning in Physical Education. Systematic Review of the Last Five Years. Research Quarterly for Exercise and Sport. Scopus. https://doi.org/10.1080/02701367.2020.1719276

Hiley, M. J., Schmid, N., \& Yeadon, M. R. (2019). How do technique and coordination change during learning of a whole-body task: Application to the upstart in gymnastics. Journal of Sports Sciences, 37(20), 2374-2380. Scopus. https://doi.org/10.1080/02640414.2019.1634413 
Peng, J., Li, A., \& Zhu, Q. (2018). Motor expertise interacts with physical enactment to enhance action memory. Journal of Sports Sciences, 36(2), 198-205. Scopus. https://doi.org/10.1080/02640414.2017.1291985

Khudolii, O., Iermakov, S., \& Bartik, P. (2020). Didactics: Methodological Basis of Motor Learning in Children and Adolescents. Journal of Learning Theory and Methodology, 1(1), 5-13. https://doi.org/10.17309/jltm.2020.1.01

Khudolii, O. (2019). Research Program: Modeling of Young Gymnasts' Training Process. Teoriâ ta Metodika FizičnogoVihovannâ, 19(4), 168-178. https://doi.org/10.17309/tmfv.2019.4.02

Ivashchenko, O. (2020). Research Program: Modeling of Motor Abilities Development and Teaching of Schoolchildren. Teoriâ ta Metodika Fizičnogo Vihovannâ, 20(1), 32-41. https://doi.org/10.17309/tmfv.2020.1.05

Ivashchenko, O., Berezhna, H., \& Cieślicka, M. (2020). Motor Skills in the Structure of Physical Fitness of 7-Year-Old Boys. Journal of Learning Theory and Methodology, 1(1), 14-19. https://doi.org/10.17309/jltm.2020.1.02

Ivashchenko, O., \& Sirichenko, D. (2020). Structure of Motor Fitness of 7-Year-Old Girls. Journal of Learning Theory and Methodology, 1(1), 20-25. https://doi.org/10.17309/jltm.2020.1.03 (in Ukrainian)

Marchenko, S., \& Kovalenko, K. (2020). Optimization of Teaching Boys Aged 10 Mae-Geri (Front Kick) Technique in Kyokushin Karate. Journal of Learning Theory and Methodology, 1(1), 33-39. https://doi.org/10.17309/jltm.2020.1.05 (in Ukrainian)

Ivashchenko, O., Khudolii, O., Iermakov, S., Chernenko, S., \&Holovko, A. (2015). Pedagogical Control of Motor Readiness of Junior School Boys. Teoriâ ta Metodika FizičnogoVihovannâ, (2), 32-40. https://doi.org/10.17309/tmfv.2015.2.1140 (in Ukrainian)

Ivashchenko, O., Iermakov, S., Khudolii, O., Cretu, M., \& Potop, V. (2017). Level of physical exercises' mastering in structure of 11-13 yrs age boys' motor fitness. Pedagogics, Psychology, Medical-Biological Problems of Physical Training and Sports, 21(5), 236-243. https://doi.org/10.15561/18189172.2017.0506

Khudolii, O., Ivashchenko, O., \& Chernenko, S. (2015). Simulation of junior shcoolchildren's training to acrobatic exercises and vaults. Pedagogics, Psychology, MedicalBiological Problems of Physical Training and Sports, 19(7), 64-71. https://doi.org/10.15561/18189172.2015.0709

Ivashchenko, O., \& Cieślicka, M. (2017). Features of evaluations of power loadsin boys 7 years old. Journal of Education, Health and Sport, 7(1), 175-183. http://dx.doi.org/10.5281/zenodo.249184

Cieślicka, M., \& Ivashchenko, O. (2017). Features of formation of the cumulative effect of power loads in boys 7 years old. Journal of Education, Health and Sport, 7(1), 198-208. http://dx.doi.org/10.5281/zenodo.250599

Hellin, M., Garcia-Jimenez, J. V., \& Garcia-Pellicer, J. J. (2019a). Intensity of physical education lessons in children according to the type of activity: Soccer, badminton, aerobics and motor skills. Journal of Physical Education and Sport, 19(1), 603-610. Scopus.

https://doi.org/10.7752/jpes.2019.01088

Hellin, M., Garcia-Jimenez, J. V., \& Garcia-Pellicer, J. J. (2019b). Intensity of physical education lessons in children according to the type of activity: Soccer, badminton, aerobics and motor skills. Journal of Physical Education and Sport, 19, 148-155. Scopus. https://doi.org/10.7752/jpes.2019.s1022

Groffik, D., Mitáš, J., Jakubec, L., Svozil, Z., \& Frömel, K. (2020). Adolescents' Physical Activity in Education Systems Varying in the Number of Weekly Physical Education Lessons. Research Quarterly for Exercise and Sport. Scopus.

https://doi.org/10.1080/02701367.2019.1688754

\title{
РУХОВІ НАВИЧКИ: СТРУКТУРА РУХОВОЇ ПІДГОТОВЛЕНОСТІ ХЛОПЧИКІВ 9 РОКІВ
}

\author{
Дмитро Петров ${ }^{2 \mathrm{ABCD}}$, Олег Худолій ${ }^{1 \mathrm{ABCD}}$, Мирослава Цислицька ${ }^{3 \mathrm{ABCD}}$ \\ ${ }^{1}$ Харківський національний педагогічний університет імені Г. С. Сковороди \\ ${ }^{2}$ Медичний колегіум: Бидгощ, Куявсько-Поморське воєводство \\ Авторський вклад: А - дизайн дослідження; В - збір даних; C - статаналіз; D - підготовка рукопису; Е - збір коштів \\ Реферат. Статья: 6 с., 2 табл., 1 рис., 26 джерела.
}

Мета дослідження - визначити місце рухових навичок у структурі рухової підготовленості хлопчиків 9 років.

Матеріали і методи.У дослідженні прийняли участь 48 хлопчиків 9 років. Діти та їхні батьки були інформовані про всі особливості дослідження і дали згоду на участь в експерименті. У дослідженні використані такі методи дослідження як аналіз наукової та методичної літератури, педагогічні спостереження, тестування рухової підготовленості, ймовірнісний підхід до оцінки процесу навчання, методи математичної статистики. В експерименті контролювався рівень навченості таким вправам: лазіння по канату у 2 прийоми, лазіння по канату у 3 прийоми, підйом переворотом в упор махом однією.

Результати. За рівнем підготовленості хлопчики 9 років $є$ однорідними за розвитком «прудкості», «координації рухів», «швидкісної сили» та «витривалості», неоднорідними - за розвитком гнучкості, сили рук і вестибулярної стійкості, рівнем навченості лазіння по канату. 
Найбільш інформативними показниками, які визначають рівень рухової підготовленості дівчаток 9 років є: No 12 «Лазіння по канату у 2 прийоми, рівень навченості» $(r=0,960)$; No 13 «Лазіння по канату у 3 прийоми, рівень навченості» $(r=0,960)$; No 14 «Підйом переворотом в упор махом однією, рівень навченості» $(r=0,875)$; No 10 «Час збереження стійкого положення - стійка на одній нозі з закритими очима, с» $(r=0.683)$.

Висновки. На основі факторного аналізу встановлено, що рівень навченості вправам на $24.287 \%$ визначає варіацію результатів тестування, а формування рухових навичок має пріорітет в освітньому процесі у молодшій школі.

Рівень навченості лазінню по канату свідчить про те, що вправи є малодоступними для хлопчиків 9 років. На основі аналізу даних можна стверджувати, що комплексний розвиток рухових здібностей забезпечує формування рухових навчок, а підвищення рівня розвитку сили згиначів рук у хлопців 9 років дозволить позитивно впливати на ефективність навчального процесу.

Ключові слова: хлопчики 9 років, рухові навички, рухові здібності, факторний аналіз.

\section{Information about the authors:}

Petrov Dmytro: dimasik.petrov13@gmail.com; https://orcid.org/0000-0001-5486-1947; H. S. Skovoroda Kharkiv National Pedagogical University, Department of Theory and Methodology of Physical Education, Alchevskykh St, 29, Kharkiv, 61002, Ukraine.

Khudolii Oleg: khudolii.oleg@gmail.com; https://orcid.org/0000-0002-5605-9939; H. S. Skovoroda Kharkiv National Pedagogical University, Department of Theory and Methodology of Physical Education, Alchevskykh St, 29, Kharkiv, 61002, Ukraine.

Cieślicka Mirosława: cudaki@op.pl; https://orcid.org/0000-0002-0407-2592; Collegium Medicum: Bydgoszcz, Kujawsko Pomorskie, Chodkiewicza St, 30, 85-064 Bydgoszcz, Poland.

Cite this article as: Petrov, D., Khudolii, O., \& Cieślicka, M. (2020). Motor Skills: Motor Fitness Structure of 9-Year-Old Boys. Journal of Learning Theory and Methodology, 1(2), 58-63. https://doi.org/10.17309/jltm.2020.2.02

Received: 27.09.2020. Accepted: 20.10.2020. Published: 30.10.2020

This work is licensed under a Creative Commons Attribution 4.0 International License (http://creativecommons.org/licenses/by/4.0). 